\title{
Formation assessment of the professional competences of electrical engineers specialists
}

\author{
Chornyi O., Herasymenko L. * \\ Kremenchuk Mykhailo Ostrohradskyi National University, Kremenchuk, Ukraine
}

Received: $10.03 .2021 \quad$ Accepted: 27.03 .2021

\begin{abstract}
The article considers the actual problem of pedagogical diagnostics of the formation of professional competencies of engineering students. Based on a thorough analysis of the educational and professional program "Electrotechnics, electric power engineering and electromechanics" twelve professional competencies were identified, they were correlated with the program results defined in the state standard and possible diagnostic tools were proposed, such as tasks on virtual stands, tasks on physical stands, professional-focused tasks. Such an approach was due to the understanding that professional competencies are cross-curricular in nature, and the possession of them involves not only acquired knowledge, skills and abilities, but also the ability to use them in future professional activities, understanding its content and having the ability to overcome problems arising in production. A method of assessment of professional competencies is proposed, which is based on the principle of differentiation and foresees testing each specific competence using three diagnostic tools, which provided the identification of the level of the fundamental and practical knowledge, ability to work with equipment and solve unusual situations that may arise in production. The following methods were used in the study. Theoretical - analysis and synthesis of research related to pedagogical diagnostics, works in which methods of information visualization are analyzed; design for the development of a program-designer "star of competencies" using the software package MATLAB. Empirical - expert assessment to identify tools for diagnosing the formation of professional competencies common among teachers; diagnostics of formation of professional competences of students by means of testing, interrogation. The visual image of the "competence star" is offered, which allowed to solve a number of tasks: to provide ease and speed of perception of the learning outcome; informational content due to the simultaneous presentation of the results of the formation of twelve competencies and the ability to analyze each separately; to realize better the level of achievements according to the formation of the program results defined in the educational standard.

Key words: training of specialists in electric engineering, professional competencies, pedagogical diagnostics, diagnostic tools, visualization of the level of formation of professional competencies.
\end{abstract}

\section{Оцінка сформованості фахових компетентностей}

\author{
Чорний О. П., Герасименко Л. В. \\ Кременчуцький національний університет імені Михайла Остроградського, Кременчук, Україна
}

\begin{abstract}
Анотація. У статті розглянуто актуальну проблему педагогічної діагностики сформованості фрахових компетентностей студентів інженерних спеціальностей. На основі грунтовного аналізу освітньо-професійної програми «Електротехніка, електроенергетика та електромеханіка» виділено дванадцять фрахових компетентностей, співвіднесено їх з програмними результатами, визначеними у державному стандарті та запропоновано можливі засоби діагностики, як-от завдання на віртуальних стендах, завдання на фізичних стендах, професійно-орієнтовані завдання. Таких підхід було зумовлено розумінням того, що фахові компетентності мають надпредметний характер, а володіння ними передбачає не тільки здобуті знання, вміння й навички, а й можливість їх використовувати у майбутній професійній діяльності, розуміючи ї̈ зміст і маючи здатність подолання проблем, що виникають на виробництві. Запропоновано методику оцінки фрахових компетентностей, яка грунтується на принципі диференціації і передбачає перевірку кожної окремо визначеної компетентності за допомогою використання трьох засобів діагностики, що забезпечило виявлення рівня фундаментальних і практичних знань, вміння працювати з обладнанням і розв'язувати нестандартні ситуації, що можуть виникати на виробництві. У дослідженні було використано такі методи. Теоретичні - аналіз і синтез
\end{abstract}

\footnotetext{
Corresponding Author: Chornyi Oleksii. Phone: +380675417900. E-mail: alekseii.chornyi@gmail.com Kremenchuk Mykhailo Ostrohradskyi National University, vul. Pershotravneva, 20, Kremenchuk, Ukraine.

Відnовідальний автор: Чорний Олексій Петрович. Тел. +380675417900. E-mail: alekseii.chornyi@gmail.com Кременчуцький національний університет імені Михайла Остроградського, вул. Першотравнева, 20, Кременчук, Україна
} 
досліджень, що стосувалися педагогічної діагностики, праць, у яких проаналізовано способи візуалізації інформації; проектування для розробки програми-конструктора «зірки компетнтностей» за допомогою програмного пакету MATLAB. Емпіричні - експертне оцінювання для виявлення засобів діагностики сформованості фахових компетентностей, поширених між викладачами; діагностика сформованості фахових компетентностей студентів за допомогою тестування, опитування. Запропоновано візуальний образ «зірка компетентностей», яка дозволила розв'язати низку завдань: забезпечити легкість і швидкість сприймання результату навчання; інформативність завдяки одночасному представленню результатів сформованості дванадцяти компетентностей і можливість аналізу кожної окремо; краще усвідомити свій рівень досягнень відповідно до сформованості програмних результатів, визначених в освітньому стандарті.

Ключові слова: підготовка фахівців з електричної інженерії, професійні компетентності, педагогічна діагностика, засоби діагностики, візуалізація рівня сформованості професійних компетентностей.

\title{
Оценка сформированности специальных компетентностей
}

\author{
Черный А. П., Герасименко Л. В. \\ Кременчугский национальный университет имени Михаила Остроградского, Кременчуг, Украина
}

\begin{abstract}
Аннотация. В статье рассмотрена актуальная проблема педагогической диагностики сформированности специальных компетентностей студентов инженерных специальностей. На основании анализа образовательно-профессиональной программы «Электротехника, электроэнергетика и электромеханика» выделены двенадцать специальных компетентностей, соотнесены с программными результатами, представленными в стандарте, и предложены возможные средства диагностики: задания на виртуальных стендах, задания на физических стендах, профессионально-ориентированные задачи. Такой подход был обусловлен пониманием того, что профессиональные компетентности имеют надпредметный характер, а овладение ими предполагает не только сфрормированные знания, умения и навыки, но и возможность их использовать в будущей профессиональной деятельности, понимая ее смысл и имея способность преодоления проблем, возникающих на производстве. Предложена методика оценки специальных компетентностей, которая основывается на принципе дифференциации и предусматривает проверку каждой отдельно взятой компетентности с помощью использования трех средств диагностики. Это обеспечило выявление уровня фундаментальных и практических знаний, умение работать с оборудованием и решать нестандартные ситуации, которые могут возникать на производстве. В исследовании были использованы теоретические методы - анализ и синтез исследований, касающиеся педагогической диагностики, работ, в которых проанализированы способы визуализации информации; проектирования для разработки программыконструктора «звезды компетнтностей» с помощью программного пакета MATLAB. Эмпирические экспертная оценка для выявления средств диагностики сформированности специальных компетентностей, наиболее используемых преподавателями; диагностика сфрормированности специальных компетентностей студентов с помощью тестирования, опроса. Разработан визуальный образ оценки сформированных компетентностей - «звезда компетентностей», которая позволила решить ряд задач: обеспечить легкость и скорость восприятия результата обучения; информативность благодаря возможности одновременно представить результаты ссрормированности двенадцати компетентностей и при этом проанализировать каждую отдельно; лучше осознать свой уровень достижений относительно программных результатов, представленных в образовательном стандарте.
\end{abstract}

Ключевые слова: подготовка специалистов по электрической инженерии, специальные компетентности, педагогическая диагностика, средства диагностики, визуализация уровня сформированности специальных компетентностей.

\section{Bcmyn}

Зміна парадигми вищої освіти, зумовлена компетентнісним підходом, змінила акценти й пріоритети підготовки фахівців XXI століття. На перший план виступають завдання, пов'язані зі створенням умов для реалізації студентами своїх цінностей, інтересів і можливостей, підготовки їх до роботи в умовах сучасного виробництва, нестабільності соціально-економічної ситуації, соціальних викликів, активної самостійної роботи, спрямованої на самореалізацію. Для виживання в жорсткій конкурентній боротьбі важливим $€$ фахівець 3 низкою сформованих соціальних та професійних компетентностей, які демонструють його реальні можливості і $є$ показником якості підготовки.

Питання компетентнісного підходу активно розвивається в педагогічній науці [1, 4, 5]; методика формування загальних, професійних компетенетностей майбутніх фахівців технічних спеціальностей розробляється у працях І. Кузьміченко [2], Л. Герасименко [3], Б. Мокіна [6]. 
Аналіз наукової літератури свідчить про сталий інтерес учених і до проблем професійної підготовки майбутніх інженерів, зокрема теоретичні основи професійної освіти відображені у дослідженнях М. Згуровського [7], А. Кокарєвої [8], М. Лазарєва, О. Пономарьова, О. Романовського [9], Л. Товажнянського [7] та інших. Практичні питання організації освітнього процесу майбутніх фрахівців 3 електричної інженерії висвітлювали А. Гладир, обгрунтовуючи необхідність інтегрованого підходу до викладання спеціальних фахових дисциплін [10], М. Загірняк, характеризуючи шляхи забезпечення якісної підготовки студентів галузі електрична інженерія [11], О. Чорний, розробляючи питання віртуальних лабораторних комплексів [12].

Не зважаючи на актуальність питання фрормування компетентностей, у практиці ЗВО відсутня нормативна методика оцінки набутих компетентностей. Адже поняття компетентності значно ширше сумарного уявлення про засвоєні знання, вміння й навички, оскільки передбачає їх ефективне використання для розв'язання відповідних проблем на виробництві.

Складності в оцінці сформованості компетентностей пов'язані з тим, що процес їх формування тривалий, надпредметний і залежить від успішного виконання всіх видів робіт, проходження усіх видів контролю: від поточного до підсумкового, а також використання широкого спектру засобів діагностики. Підсумкова оцінка, виставлена на іспиті, вказує на рівень сформованості знань, умінь і навичок, але, на жаль, не виявляє всіх особистісних і професійних здобутків майбутнього фрахівця, зокрема розуміння специфіки виробничого процесу, вміння орієнтуватися в надзвичайній ситуації, що виникла на виробництві, тощо. Колектив авторів стоїть на позиції того, що виявлення рівня сформованості компетентностей - розгорнутий у часі процес, який не обмежується проведенням підсумкової діагностики, а потребує розробки інноваційних форм і методів навчання, здатних максимально наблизити освітній процес до умов сучасного виробництва й забезпечити професійно-орієнтовану підготовку фахівців й, безумовно, об'єктивну діагностику сформованості тієї чи іншої компетентності протягом навчання. Аналіз наукової літератури показав, що проблема системної діагностики професійних компетенцій майбутнього інженера у вищому навчальному закладі до цього часу в цілісному вигляді не розглядалася і $є$ актуальною.

Метою даного дослідження є розробка методики оцінювання фахових компетентностей майбутніх інженерів та візуалізація отриманих результатів.

\section{II Матеріал і методи дослідження}

Кожна з компетентностей, що впливає на сформованість програмних результатів, потребує конкретизації й структурування у виділенні істотних ознак проявів у конкретних ссрерах професійної діяльності чи то конкретних ситуаціях. Це вимагає розробки різних засобів діагностики, які б об'єктивно перевіряли визначені якості.

Запропоновані у даній статті засоби діагностики визначені на основі напрацьованого досвіду роботи викладачів Навчально-наукового інституту електромеханіки, енергозбереження і систем управління Кременчуцького національного університету імені Михайла Остроградського.

Опитування 54 викладачів інституту дозволило з'ясувати, що дослідження лише на синтезованих математичних моделях призвело до того, що у студентів виникли труднощі в розумінні фізичної природи електромагнітних і механічних процесів реальних об'єктів [11]. Це стало поштовхом для розробки й дослідження віртуальних комплексів. Вони імітують реальні фрізичні об'єкти, створені за допомогою комп'ютерних систем, які можуть виступати замінниками реальних виробничих приладів і процесів, забезпечують візуальні і звукові ефекти на основі технології безконтактної інформаційної взаємодії, яка дозволяє користувачеві безпосередньо діяти за допомогою спеціальних сенсорних пристроїв і пристроїв керування [11]. Робота з віртуальними комплексами дозволяє наблизити студента до умов реального виробництва, дозволяє формувати вміння діагностики, управління виробничим обладнанням та технологічними процесами, здатність знаходити причини аварійних ситуацій на виробництві та навчатися їх усувати тощо. При створенні віртуальних комплексів використовувалося програмне забезпечення LabView, яке являє собою універсальну систему програмування, орієнтовану на вирішення завдань управління інструментальними засобами вимірювання, збору, обробки i представлення експериментальних даних. Проте робота з віртуальними комплексами і тренажерами 
має переважно аналітичний характер, хоча й дозволяє засвоїти зміст і послідовність певних дій, необхідних для майбутнього фахівця з електричної інженерії на виробництві.

Подальший розвиток професійних компетентностей забезпечується виконанням завдань на фрізичних стендах, де необхідно виявити не тільки теоретичні знання, аналітичні вміння, а й операційномоторні навички роботи з обладнанням: увімкнути (вимкнути) систему, усунути пошкодження, здійснити вибір обладнання, встановити рівні сигналів завдання, провести дослідження за методичними вказівками і за завданням на наукове дослідження, наприклад, «Використовуючи стенд, дослідити електромеханічні і регулювальні властивості електромеханічної системи, її статичні характеристики і динамічні режими», отримати навички планування дослідницького експерименту і обробки отриманих експериментальних даних, графічної візуалізації результатів роботи і відображення їх у вигляді звіту.

Значущу роль в оцінці сформованості професійних компетентностей студентів відіграють професійно-орієнтовані завдання. Вони дозволяють розв'язати реально можливу виробничу ситуацію, використовуючи синтез засобів фахових навчальних дисциплін. Цей вид завдань максимально близький до ситуаційного моделювання і покликаний виявити рівень сформованості професійного мислення, аналітичних здібностей, теоретичної підготовки, розуміння виробничої ситуації, можливість оцінити ії, що дозволяє прийняти правильні рішення в ситуації, що склалася на виробництві. Адже компетентний фахівець має не тільки розуміти суть проблеми, але й уміти розв'язувати ї̈ практично, демонструючи свій власний метод [6].

У дослідженні, яке проводилося у Кременчуцькому національному університеті імені Михайла Остроградського, взяло участь 48 студентів третього курсу Навчально-наукового інституту електромеханіки, енергозбереження і систем управління. Їм було запропоновано у кінці семестру пройти підсумкове випробування 3 «Теорії електропривода», яке складалося із ста завдань і передбачало використання всіх трьох засобів діагностики, опрацьованих у процесі поточного, тематичного, модульного контролю: професійно-орієнтовані завдання; завдання на віртуальних лабораторних стендах; завдання на фізичних лабораторних стендах. На нашу думку, саме така методика діагностики допоможе виявити не тільки рівень здобутих знань і вмінь, але й можливість їх використання на практиці, розуміння виробничих процесів, нестандартних ситуацій та вміння діяти в нестандартних умовах. Що буде свідченням сформованості відповідних фрахових компетентностей [13].

Для прикладу у табл. 1 представлено фахові компетентності, програмні результати та засоби діагностики. Дослідження проводили в два етапи. На першому - йшли традиційним шляхом і виставили підсумкову оцінку за всіма завданнями. На другому етапі всі завдання підсумкової діагностики були диференційовані відповідно до перевірки конкретної компетентності. Наприклад, завдання 2, 6, 18, 78 .... спрямовані на перевірку фахової компетентності 1 (ФК); завдання 3, 10, 17, 65 - ФК 3 і т. ін. табл. 2.

Побудова візуального образу оцінки сформованості професійних компетентностей мала розв'язати низку завдань: забезпечити легкість і швидкість сприймання результату навчання; інформативність завдяки одночасному представленню результатів сформованості 12 компетентностей і можливість аналізу кожної окремо; краще усвідомити свій рівень досягнень відповідно до сформованості програмних результатів, визначених в освітньому стандарті. Для реалізації даних завдань було використано програмне забезпечення Matlab, де в якості вхідної інформації - результати діагностики розв'язаних завдань (табл. 2), а вихідної - графічний образ сформованості компетентностей та їх числове значення.

Тоді оцінка за окремою визначеною (групою) компетентностей:

$$
L_{k}=\sum_{n=1}^{N} l(k)_{n},
$$

де $k$ - номер стовпця з відповідною компетентністю, $K$ - кількість визначених компетентностей (12 для даного дослідження), $N$ - кількість завдань, $l(k)_{n}$ - оцінка по $k$-й компетентності $n$-го завдання.

У випадку повної ссормованості і володіння компетентностями, що передбачені завданнями освітнього процесу за окремою начальною дисципліною або групою навчальних дисциплін, буде виконуватись рівність:

$$
L_{1}=L_{2}=\ldots=L_{K}=100 \% \text {. }
$$


Табл. 1. Професійні компетентності майбутніх інженерів-електромеханіків ОПП «Електроенергетика, електротехніка та електромеханіка» та засоби їх діагностики

\begin{tabular}{|c|c|c|}
\hline Професійні компетентності & $\begin{array}{c}\text { Програмні результати } \\
\text { навчання }\end{array}$ & $\begin{array}{c}\text { Засоби } \\
\text { діагностики }\end{array}$ \\
\hline $\begin{array}{l}\text { 3) здатність складати моделі електротехнічних, } \\
\text { електромеханічних об'єктів; здатність вирішувати } \\
\text { практичні задачі із залученням методів математики, } \\
\text { фізики; } \\
\text { 5) засвоєння принципів роботи електромеханічного } \\
\text { устаткування; } \\
\text { 9) здатність вирішувати практичні задачі із } \\
\text { застосуванням систем автоматизованого } \\
\text { проектування і розрахунків ; } \\
\text { 11) дослідження характеристики режимів роботи та } \\
\text { енергетичних процесів електроприводів постійного і } \\
\text { змінного струму; } \\
\text { 12) здатність оперативно вживати есрективні заходи в } \\
\text { умовах надзвичайних (аварійних) ситуацій в } \\
\text { електроенергетичних та електромеханічних системах. }\end{array}$ & $\begin{array}{l}\text { 4) Знати рівняння руху } \\
\text { електропривода; методики } \\
\text { розрахунку механічної } \\
\text { частини електропривода; } \\
\text { способів керування } \\
\text { двигунами постійного та } \\
\text { змінного струму; методів } \\
\text { вибору електродвигунів за } \\
\text { потужністю та уміти } \\
\text { аналізувати та проектувати } \\
\text { схеми автоматичного } \\
\text { керування } \\
\text { електромеханічних систем } \\
\text { типових технологічних } \\
\text { призначень та } \\
\text { промислових } \\
\text { електроприводів; }\end{array}$ & $\begin{array}{l}\text { 1) Просресійно- } \\
\text { орієнтовані } \\
\text { завдання; } \\
\text { 2) завдання на } \\
\text { віртуальних } \\
\text { лабораторних } \\
\text { стендах; } \\
\text { 3) завдання на } \\
\text { фізичних } \\
\text { лабораторних } \\
\text { стендах }\end{array}$ \\
\hline $\begin{array}{l}\text { 2) здатність вирішувати комплексні, спеціалізовані } \\
\text { задачі і практичні проблеми, пов'язані з проблемами } \\
\text { виробництва, передачі та розподілення електричної } \\
\text { енергії. } \\
\text { 3) здатність складати моделі електротехнічних, } \\
\text { електромеханічних об'єктів; здатність вирішувати } \\
\text { практичні задачі із залученням методів математики, } \\
\text { фізики; } \\
\text { 6) здатність використовувати типові електронні } \\
\text { компоненти для складання схем інверторів, } \\
\text { перетворювачів, випрямлячів, розуміти принципи } \\
\text { роботи силової перетворювальної техніки; } \\
\text { 7) здатність застосовувати методи розрахунку } \\
\text { надійності електротехнічних та електромеханічних } \\
\text { систем, використовувати практичні навички } \\
\text { налагодження та випробовування електромеханічного } \\
\text { обладнання; } \\
\text { 10) оволодіння програмним інструментарієм для } \\
\text { моделювання; }\end{array}$ & $\begin{array}{l}\text { 5) Здатність застосовувати } \\
\text { прикладне програмне } \\
\text { забезпечення, } \\
\text { мікроконтролери та } \\
\text { мікропроцесорну техніку } \\
\text { для вирішення практичних } \\
\text { проблем у професійній } \\
\text { діяльності; }\end{array}$ & $\begin{array}{l}\text { 1) Професійно- } \\
\text { орієнтовані } \\
\text { завдання; } \\
\text { 2) завдання на } \\
\text { віртуальних } \\
\text { лабораторних } \\
\text { стендах; } \\
\text { 3) завдання на } \\
\text { фізичних } \\
\text { лабораторних } \\
\text { стендах }\end{array}$ \\
\hline
\end{tabular}

Табл. 2. Результати діагностики сформованості професійних компетентностей

\begin{tabular}{|c|c|c|c|c|c|c|c|c|c|c|c|c|c|}
\hline \multirow[t]{3}{*}{ Студент } & \multicolumn{4}{|c|}{ Оцінка компетентності 1* } & \multicolumn{4}{|c|}{ Завдання 2} & & \multicolumn{4}{|c|}{ Завдання N } \\
\hline & \multicolumn{13}{|c|}{ Визначені компетентності $(k)$} \\
\hline & 1 & 2 & $\ldots$ & $\mathrm{K}$ & 1 & 2 & $\ldots$ & $\mathrm{K}$ & $\ldots$ & 1 & 2 & .. & $\mathrm{K}$ \\
\hline \multicolumn{14}{|l|}{ Студент 1} \\
\hline$x^{2}+y_{1}$ & & & & & & & & & & & & & \\
\hline \multicolumn{14}{|l|}{ Студент 19} \\
\hline$\ldots$ & & & & & & & & & & & & & \\
\hline
\end{tabular}


Для зручності візуальної оцінки компетентностей розташуємо їх по колу, тоді їх вершини утворять фігуру, яка матиме вигляд «зірки». Ї̈̈ симетрія залежить від оцінки рівня сформованості компетентності, перевіреного комплексом засобів діагностики.

Припустимо, що оцінка рівня сфрормованості професійних компетентностей здійснюється трьома засобами діагностики, що характеризують знання, професійно-орієнтовані уміння й навички, тобто відповідно визначають володіння теоретичним матеріалом $\left(z_{1}\right)$, здатність вирішувати інженерні задачі ( $z_{2}$ ) й вміння працювати з обладнанням $\left(z_{3}\right)$. Беручи до уваги, що вони рівнозначно об'єктивно діагностують сформованість компетентностей, перелічені засоби утворять у декартовій координатній системі зображуючий вектор, що $є$ інтегральною оцінкою $(\mathbb{Z})$, а проекції вектору - оцінки відповідних засобів діагностики, що показано на рис. 1. Довжина $\mathbb{Z}$ визначена через проекції $z_{i}$ :

$$
\mathbb{Z}^{2}=\sum_{i=1}^{3} z_{i}^{2} .
$$

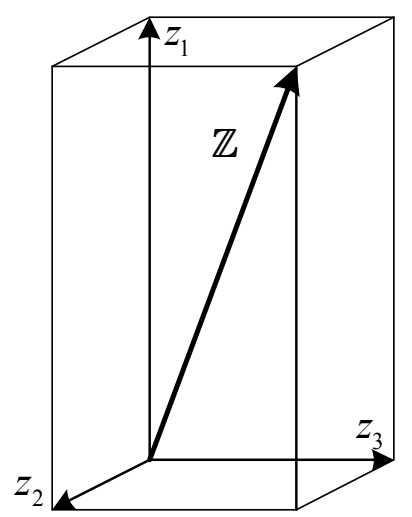

Рис. 1. Формування інтегральної оцінки сформованості компетентності

Перейдемо від декартових координат до сфреричних і отримаємо $\vartheta$ кут нахилу $\mathbb{Z}$, який визначає відхилення вершини «зірки» (рис. 2):

$$
\vartheta=\operatorname{arctg} \frac{\sqrt{z_{2}^{2}+z_{3}^{2}}}{z_{1}}
$$

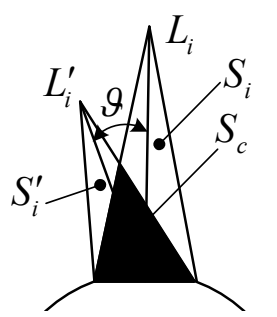

Рис. 2. Вплив оцінки засобу діагностики на відхилення вершини «зірки»

Тепер оцінку за відповідною компетентністю будемо шукати як площу перетину вершин «зірки», визначену за традиційною і запропонованою методикою, відповідно площі $S$ і $S^{\prime}$, яка являє собою полігон, площу якого можна знайти за фрормулою Гауса [21, 22].

$$
S_{i} \cap S_{i}^{\prime}=\frac{1}{2} \sum_{i=1}^{n-1}\left(x_{i} y_{i+1}-x_{i+1} y_{i}\right),
$$

де $x_{0}=x_{n}, y_{0}=y_{n} \cdot n$ - кількість сторін полігону, $\left(x_{i}, y_{i+1}\right), i=1,2, \ldots, n$ - координати вершин полігону, $S_{i}-$ оцінка отримана в результаті традиційного підсумкового оцінювання; $S_{i}^{\prime}$ - у результаті дифреренціації завдань відповідно до визначених компетентностей. Площина зафрарбована - реальний рівень сформованості просресійних компетентностей.

Аналіз результатів табл. 3 та рис. 2, 3 демонструє істотні розходження між рівнем сформованості професійних компетентностей, перевірений за традиційною підсумковою діагностикою, запропонованою 
авторами. Це зумовлено тим, що диференційована перевірка окремих компетентностей дозволяє більш детально перевірити усі складники компетентності і виявити ті, що потребують доопрацювання: знання, уміння використовувати теоретичні знання на практиці, розв'язувати виробничі ситуації, працювати 3 виробничим обладнанням тощо.

\section{III Результати}

Результати оволодіння компетентностями, розрахованими за наведеною методикою, покажемо для студента №19 (табл.2). Аналіз результатів діагностики, дозволив встановити, що оцінка компетентності 1 має значення 75 балів. Результати розрахунків зведемо в табл. 3.

Табл. 3. Зведені результати розрахунків оволодіння студентом №19 компетентністю «Знання фундаментальних і фахових основ дисципліни»

\begin{tabular}{|c|c|c|}
\hline Оцінка компетентності $L_{1}, \%$ & Кут нахилу $\vartheta$, град & Оцінка компетентності $O_{19}, \%$ \\
\hline 75 & 15,6 & 52,8 \\
\hline
\end{tabular}

Оцінку розрахуємо як

$$
\mathrm{O}_{19}=\sum_{i=1}^{n=12}\left(\frac{S_{i} \cap S_{i}^{\prime}}{S_{i}}\right) 100 \%
$$

Якщо порівняти з результатами підсумкового оцінювання (табл.2) - 75 балів, оцінка сфрормованості компетентності складає 52,8 балів.

Викладемо алгоритм розрахунку оцінки сфрормованості компетентності.

Знайдемо координати вершини $\left(x_{30}, y_{30}\right)$ i $\left(x_{31}, y_{31}\right)$ (рис. 3):

- для вершини $\left(x_{30}, y_{30}\right)$

- для вершини $\left(x_{31}, y_{31}\right)$

$$
\begin{aligned}
& \left(y_{30}-y_{1}\right)^{2}+\left(x_{30}-x_{1}\right)^{2}=d_{1}^{2}+L_{0}^{2}-2 L_{0} d_{1} ; \\
& \left(y_{30}-y_{2}\right)^{2}+\left(x_{30}-x_{2}\right)^{2}=d_{2}^{2}+L_{0}^{2}-2 L_{0} d_{2},
\end{aligned}
$$

$$
\begin{aligned}
& \left(y_{31}-y_{1}\right)^{2}+\left(x_{31}-x_{1}\right)^{2}=d_{1}^{2}+L_{1}^{2}-2 L_{0} d_{1} \cos \left(\frac{\pi}{2}+\vartheta\right) \\
& \left(y_{31}-y_{2}\right)^{2}+\left(x_{31}-x_{2}\right)^{2}=d_{2}^{2}+L_{1}^{2}-2 L_{0} d_{2} \cos \left(\frac{\pi}{2}-\vartheta\right),
\end{aligned}
$$

де $d_{1}^{2}=\left[x_{1}-\left(\frac{x_{1}+x_{2}}{2}\right)\right]^{2}+\left[y_{1}-\left(\frac{y_{1}+y_{2}}{2}\right)\right]^{2}, d_{2}^{2}=\left[x_{2}-\left(\frac{x_{1}+x_{2}}{2}\right)\right]^{2}+\left[y_{2}-\left(\frac{y_{1}+y_{2}}{2}\right)\right]^{2}$.

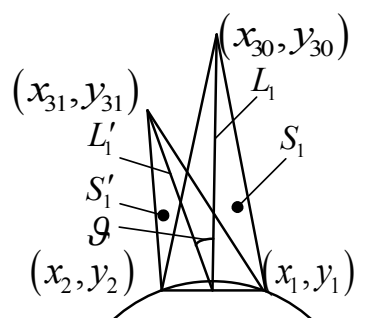

a)

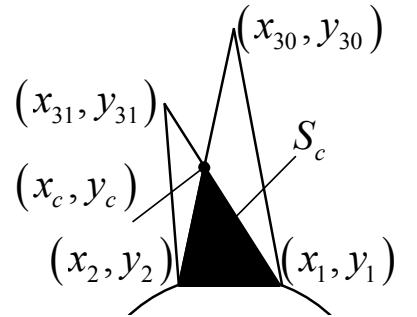

b)

Рис. 3. Побудова візуального образу сформованості професійних компетентностей: а - побудова променів зірки; б - визначення реального рівня сфрормованості професійних компетентностей

За фрормулою Гауса $[21,22]$ знайдемо площі трикутників:

- для $\left[\left(x_{1}, y_{1}\right),\left(x_{2}, y_{2}\right),\left(x_{30}, y_{30}\right)\right]$ :

$$
S_{1}=\frac{1}{2}\left(x_{1} y_{2}+x_{2} y_{30}+x_{30} y_{1}-x_{2} y_{1}-x_{30} y_{2}-x_{1} y_{30}\right)
$$


- для $\left[\left(x_{1}, y_{2}\right),\left(x_{2}, y_{2}\right),\left(x_{31}, y_{31}\right)\right]$

$$
S_{1}^{\prime}=\frac{1}{2}\left(x_{1} y_{2}+x_{2} y_{31}+x_{31} y_{1}-x_{2} y_{1}-x_{31} y_{2}-x_{1} y_{31}\right)
$$

Знайдемо точку перетину прямих $\left[\left(x_{1}, y_{1}\right),\left(x_{31}, y_{31}\right)\right] \mathrm{i}\left[\left(x_{2}, y_{2}\right),\left(x_{30}, y_{30}\right)\right]$ :

$$
\begin{aligned}
& x_{c}=\frac{\left(x_{1} y_{31}-x_{31} y_{1}\right)\left(x_{2}-x_{30}\right)-\left(x_{2} y_{30}-x_{30} y_{2}\right)\left(x_{1}-x_{31}\right)}{\left(x_{1}-x_{31}\right)\left(y_{2}-y_{30}\right)-\left(x_{2}-x_{30}\right)\left(y_{1}-y_{31}\right)} \\
& y_{c}=\frac{\left(x_{1} y_{31}-x_{31} y_{1}\right)\left(y_{2}-y_{30}\right)-\left(x_{2} y_{30}-x_{30} y_{2}\right)\left(y_{1}-y_{31}\right)}{\left(x_{1}-x_{31}\right)\left(y_{2}-y_{30}\right)-\left(x_{2}-x_{30}\right)\left(y_{1}-y_{31}\right)}
\end{aligned}
$$

Отримаємо область перетину трикутників $\left[\left(x_{1}, y_{1}\right),\left(x_{2}, y_{2}\right),\left(x_{30}, y_{30}\right)\right] \mathrm{i}\left[\left(x_{1}, y_{2}\right),\left(x_{2}, y_{2}\right),\left(x_{31}, y_{31}\right)\right] \mathrm{y}$ вигляді трикутника $\left[\left(x_{1}, y_{2}\right),\left(x_{2}, y_{2}\right),\left(x_{c}, y_{c}\right)\right]$

Знайдемо площу $S_{c}$ трикутника $\left[\left(x_{1}, y_{2}\right),\left(x_{2}, y_{2}\right),\left(x_{c}, y_{c}\right)\right]$ :

$$
S_{c}=\frac{1}{2}\left(x_{1} y_{2}+x_{2} y_{c}+x_{c} y_{1}-x_{2} y_{1}-x_{c} y_{2}-x_{1} y_{c}\right)
$$

Побудова «зірки компетентностей» виконана за допомогою Мatlab. Фрагмент коду показаний у алгоритмі 1:

\section{Алгоритм 1 - Формування «зірки компетентностей»}

load vertexes;

$\mathrm{v}=$ vertexes;

$\% \mathrm{X}=[\ldots] ; \%$ «вхідні координати»

figure;

for $i=1$ :length $(v)$

$X=[v(i, 1) v(i, 5) v(i, 3) v(i, 1)] ;$

$Y=[v(i, 2) v(i, 6) v(i, 4) v(i, 2)] ;$

$\operatorname{plot}\left(X, Y,{ }^{\prime}--m^{\prime}\right) ;$

hold on

end

for $i=1$ :length $(v)$

$X=[v(i, 1) v(i, 7) v(i, 3) v(i, 1)]$

$Y=[v(i, 2) v(i, 8) v(i, 4) v(i, 2)] ;$

$\operatorname{plot}\left(X, Y,{ }^{\prime}--b^{\prime}\right) ;$

hold on

end

for $i=1$ :length $(v)$

$X=[v(i, 1) v(i, 9) v(i, 3) v(i, 1)]$

$Y=[v(i, 2) v(i, 10) v(i, 4) v(i, 2)] ;$

fill $\left(X, Y, r^{\prime}\right)$;

hold on

end

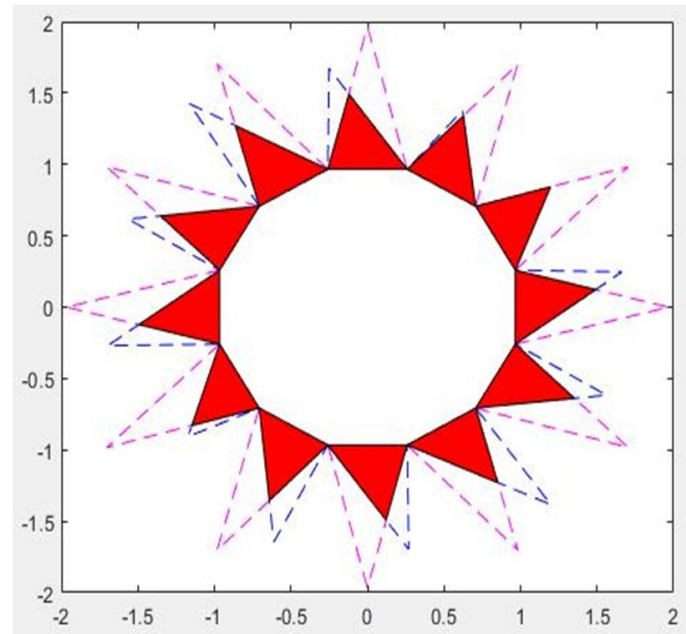

Рис. 4. «Зірка» сформованих компетентностей 


\section{IV Обговорення}

Зміст парадигми сучасного оцінювання полягає в тому, щоб продемонструвати студенту можливі шляхи подальшого розвитку і вдосконалення, узагальнення набутих знань, актуалізації вмінь, формування професійних компетентностей.

Вивчення сучасних досліджень, присвячених впровадженню компетентнісного підходу до оцінки якості підготовки майбутніх фахівців, дозволяють виділити у світовій практиці три основні методології: поведінкова (США), фрункціональна (Великобританія) й багатовимірна (Франція і Німеччина).

Поведінкова передбачає широке використання тестів, спрямованих на перевірку здатності працювати за обраною професією. На відміну від США, у Великобританії враховуються функціональні характеристики якості базових знань і результатів навчання, які співвідносяться зі знаннями й цінностями тих, хто сфрормувався як професіонал. У Німеччині оцінка компетентностей передбачає виявлення особистісних здобутків майбутнього фахівця і сформованість компетенцій після вивчення кожної навчальної дисципліни [14].

Зарубіжний досвід дозволив виявити важливі для оцінки сфоорованості компетентностей параметри: особистісні властивості, знання й уміння, вміння їх використовувати в майбутній професійній діяльності.

Вітчизняні науковці І. Звонніков [15], Л. Огнівчук [14], Н. Титова [16], А. Чернявська [17] відзначають, що традиційний сесійно-екзаменаційний контроль навчальних досягнень студентів хоч і стимулює навчальну активність студентів, проте не вирішує проблем забезпечення якості підготовки фахівців у відповідності з критеріями професіоналізму і конкурентоспроможності, які об'єктивно висуваються сучасністю і пов'язані з компетентнісним підходом. Так, Л. Огнівчук обґрунтувала оригінальну методику оцінки сформованості професійних компетентностей, запропонувавши розглядати кожну окрему компетенцію відповідно до їі структури, щоб уникнути дублювання навчального матеріалу і в майбутньому чітко сформувати комплекс діагностичних процедур; розробила математичну модель та метод оцінювання рівня сформованості компетенцій у студентів ЗВО на основі апарату нечіткої логіки та довела доцільність її використання [14].

Отже, погоджуємося з тим, що перехід від оцінювання знань здобувача з окремих дисциплін до оцінювання сформованості певної компетентності викликає лавиноподібне ускладнення процесу та критеріїв оцінювання. Адже компетенція формується у процесі вивчення групи дисциплін, викладання яких може не співпадати у часі. Середнє значення оцінок за дисциплінами, що формують компетентність, також не може бути беззаперечним показником її сфрормованості, оскільки не вирішено питання важливості впливу окремих дисциплін на цей процес. Наявність числових характеристик сфрормованості окремих компетентностей не усуває проблематику оцінювання якості підготовки спеціаліста в цілому, що актуалізує необхідність обірунтування методики на основі нечіткої логіки.

Результат діагностики являє собою достатньо розгалужену характеристику, що має відбивати вид компетентності, рівень їі сфрормованості, динаміку, рекомендації щодо вдосконалення тощо.

У такому контексті надзвичайно важливо запропонувати зручний, ефективний вид оцінки, що дозволяв би швидко зрозуміти власні навчальні досягнення. Студіювання сучасних досліджень Р. Араухо, С. Бул, Б. Вассон, Ф. Дорча, Р. Каттелана, Х. Феррейра, Д. Чедих, А. Ярового, дозволяють виділити візуалізацію як можливий ефективний інструмент аналітики для дослідження даних про успішність засвоєння навчальних курсів, ефективність виконання домашнього завдання та проектування змісту іспитів відповідно до отриманих результатів [19], оцінювання $[18,19,20]$, що одночасно може виступати формою і типом отримання та представлення інформації, спрощуючи раціонально-символьні трактовки (відмітки у тому числі) [21].

Це дозволяє студентам краще усвідомити результати свого навчання та коригувати їх, а також полегшує аналіз результатів оцінювання викладачами для коригування методики викладання.

\section{V Висновки}

Запропонована методика оцінювання професійних компетентностей дозволяє отримати більш достовірну інформацію про рівень їх ссрормованості, бо ґрунтується на принципі диференціації, i передбачає перевірку кожної окремо визначеної компетентності, а поєднання трьох засобів діагностики 
забезпечує виявлення рівня фундаментальних і практичних знань, вміння працювати з виробничим обладнанням і розв'язувати нестандартні ситуації, що можуть виникати на виробництві. Запропонований візуальний образ «зірка компетентностей» допомагає студентам миттєво отримати інформацію про якість своєї підготовки з навчальної дисципліни. Перспективи подальших досліджень вбачаються у використанні засобів візуалізації на різних етапах освітнього процесу від мотивації до сприйняття і засвоєння змісту навчальної інформації, що є корисним для забезпечення якості навчання.

\section{Бібліографічні посилання}

1. Компетентнісний підхід у сучасній освіті : світовий досвід та українські перспективи: бібліотека з освітньої політики / під заг. ред. О. В. Овчарук. К.: К.І.С., 2004. 112 с.

2. Кузьміченко І.Формування соціальнопрофресійної компетентності майбутнього інженера. Вісник ЛНУ імені Тараса Шевченка. 2014. № 23 (186).Ч. 3.С. 220-224.

3. Chornyi O., Herasymenko L. and Zelenska L. Diagnostic Assessment Of The Competency Maturity Of Electrical Engineers Through Profession-oriented problems", Problems of Automated Electrodrive. Theory and Practice (PAEP), IEEE. 2020. Pp. 423-426. doi: 10.1109/PAEP49887.2020.9240864.

4. Нізовцев А. Розробка моделі професійної компетентності інженера. Педагогічні науки: теорія, історія, інноваційні технології. 2013. № 8. С. 243-255.

5. Огороднічук I. Особливості формування компетентності майбутніх інженерів, Наука і освіта. 2013. № 1-2. С. 193197.

6. Мокін Б., Мізарний В., Мензул О. Формування професійної компетентності студентів в умовах профресійно-практичної підготовки. Вісник Вінницького політехнічного інституту. 2011. № 5. С. 199-203.

7. Канівець М. Сутність профресійної підготовки майбутніх інженерів. Проблеми та перспективи формування національної гуманістично-технічної еліти: зб.наук.праць VI Кримські педагогічні читання: «Нові педагогічні технології в освіті та формування гуманітарно-технологічної еліти»: Матеріали Міжнародної науково-практичної конфреренції, 21-24 травня 2013 р. Том 34-35 (38-39). С. 44-51.

8. Кокарєва А. М. Сучасний стан профресіональної підготовки інженерів в технічному університеті. Вісник Національного авіаційного університету. Серія: Педагогіка. Психологія. 2017. № 10. DOI: 10.18372/2411-264X.10.12509

9. Романовський О. Професійна підготовка майбутнього фахівця в контексті фундаменталізації сучасної освіти. Профресійна освіта. К.; Харків, 2009. С.132-139.

10. Гладир А. І., Пупинін С. П. Концепція викладання циклу спеціальних дисциплін фахової підготовки інженерівелектромеханіків. Вісник Кременчуцького національного університету імені Михайла Остроградського. 2008. Випуск 3(50) Частина І. С.54-58.

11. Zagirnyak M., Chornyi O., Serhiienko S. Innovative Technologies in Laboratory Workshop for Students of Technical Specialties . In: Kyiv, Proceedings of the First Ukraine Conference on Electrical and Computer Engineering (UKRCON), Kyiv, May 29-June 2, 2017. Kyiv, pp. 1216-1220. DOI: 10.1109 / UKRCON.2017.8100446.

12. Chornyi O., Serhiienko S., Yudyna A., Sydorenko V. The analysis of the process of the laboratory practicum fulfillment and the assessment of its efficiency on the basis of the distance function. In: Kremenchuk Mykhailo Ostrohradskyi National University, Modern electrical and energy systems (MEES), Proceedings of the International Conference, Kremenchuk, November 15-17 2017. Kremenchuk. Pp. 328-331. DOI: 10.1109/ MEES.2017.8248924.

13. Освітньо-професійна програма «Електроенергетика, електротехніка та електромеханіка» Режим доступу: http://saue.kdu.edu.ua/upload/documents/2020_141_prog.pdf

14. Огнівчук Л. М. Оцінювання навчальних досягнень студентів вищих навчальних закладів на основі компетентнісного підходу. Освітологічний дискурс. 2014. № 3 (7). С. 154-165.

15. Звонников В.И., Челышкова М.Б. Оценка качества результатов обучения при аттестации (компетентностный подход): учеб. пособие. М. 2012. 280 с.

16. Титова Н. М. Оцінювання навчальних досягнень студентів як наукова проблема. Науковий часопис НПУ імені М. П. Драгоманова. Педагогічні науки: реалії та перспективи. 2010. Вип. 23. С. 324-329.

17. Чернявская А. П. Оценивание учебных достижений студентов вузов. Проблемы высшей школы. 2006. № 3. С. 67-79.

18. Araújo R., Brant-Ribeiro T., Cattelan R., Amo S., Ferreira H.N.M. Personalization of interactive digital media in ubiquitous educational environments. In Proceedings of the IEEE International Conference on Systems, Man, and Cybernetics. Pp. 3955-3960. https://doi.org/10.1109/SMC.2013.675

19. Ferreira H.N.M., Ribeiro T., Araújo R., Dorça F., Cattelan R. An automatic and dynamic student modeling approach for adaptive and intelligent educational systems using ontologies and bayesian networks. In Proceedings of the 28th International Conference on Tools with Artificial Intelligence. Pp. 738-745. https://doi.org/10.1109/ICTAI.2016.0116

20. Ferreira H.N.M., Oliveira G., Araújo R., Dorça F., Cattelan R. An open model for student assessment visualization. In Proceedings of the 19th IEEE International Conference on Advanced Learning Technologies. Pp. 375-379. https://doi.org/10.1109//CALT.2019.00117

21. Ferreira H.N.M., Araújo R., Dorça F., Cattelan R. Open student modeling for academic performance visualization in ubiquitous learning environments. In Proceedings of the IEEE International Conference on Systems, Man, and Cybernetics. Pp. 641-646. https://doi.org/10.1109/SMC.2017.8122679 
22. Bull S. and Wasson B. Competence visualisation: Making sense of data from 21st-century technologies in language learning, ReCALL, vol. 28. Pp. 147-165. DOI: https://doi.org/10.1017/S0958344015000282

23. Ali L., Hatala M., Gašević D., Jovanović J. A qualitative evaluation of evolution of a learning analytics tool Comput. Educ. 2012. 58 (1). Pp. 470-489. https://doi.org/10.1016/j.compedu.2011.08.030

24. Яровий А. Про гносеологічну природу образного типу пізнання. Мультиверсум. 2006. № 56. С. 90-101.

25. Shoelace Theorem. URL: https://artofproblemsolving.com/wiki/index.php?title=Shoelace_Theorem (дата звернення13.03.2021)

26. Polygon Area. URL: https://mathworld.wolfram.com/PolygonArea.html (дата звернення13.03.2021).

\section{References}

1. Kompetentnisnyi pidkhid u suchasnii osviti : svitovyi dosvid ta ukrainski perspektyvy: biblioteka z osvitnoi polityky / pid zah. red. O. V. Ovcharuk. K.: K.I.S., 2004. 112 s. [in Ukrainian].

2. Kuzmichenko I. (2014) Formuvannia sotsialnoprofesiinoi kompetentnosti maibutnoho inzhenera. Visnyk LNU imeni Tarasa Shevchenka. № 23 (186).Ch. 3. P. $220-224$ [in Ukrainian]..

3. Chornyi O., Herasymenko L. and Zelenska L. (2020) Diagnostic Assessment Of The Competency Maturity Of Electrical Engineers Through Profession-oriented problems", Problems of Automated Electrodrive. Theory and Practice (PAEP), IEEE. P. 423-426. doi: 10.1109/PAEP49887.2020.9240864 [in Ukrainian].

4. Nizovtsev A. (2013) Rozrobka modeli profesinoi kompetentnosti inzhenera. Pedahohichni nauky: teoriia, istoriia, innovatsiini tekhnolohii. № 8. S. 243-255 [in Ukrainian].

5. Ohorodnichuk I. (2013) Osoblyvosti formuvannia kompetentnosti maibutnikh inzheneriv, Nauka i osvita. № 1-2. P. 193-197 [in Ukrainian].

6. Mokin B., Mizarnyi V., Menzul O. (2011) Formuvannia profesiinoi kompetentnosti studentiv v umovakh profesiino-praktychnoi pidhotovky. Visnyk Vinnytskoho politekhnichnoho instytutu. № 5. S. 199-203 [in Ukrainian].

7. Kanivets M. (2013) Sutnist profesiinoi pidhotovky maibutnikh inzheneriv. Problemy ta perspektyvy formuvannia natsionalnoi humanistychno-tekhnichnoi elity: zb.nauk.prats VI Krymski pedahohichni chytannia: «Novi pedahohichni tekhnolohii v osviti ta formuvannia humanitarno-tekhnolohichnoi elity»: Materialy Mizhnarodnoi naukovo-praktychnoi konferentsii, 21-24 travnia 2013 r. Tom 34-35 (38-39). S. 44-51.

8. Kokarieva, A.M. (2017). Suchasnyi stan profesiinoi pidhotovky inzheneriv $v$ tekhnichnomu universyteti [The current state of professional training of engineers at a technical university]. Proceedings of the National Aviation University. Series: Pedagogy, Psychology, 10, 1-4 [in Ukrainian].

9. Romanovskyi O. (2009) Profesiina pidhotovka maibutnoho fakhivtsia $v$ konteksti fundamentalizatsii suchasnoi osvity. Profesiina osvita. K.; Kharkiv. S.132-139 [in Ukrainian].

10. Hladyr A. I., Pupynin S. P. (2008) Kontseptsiia vykladannia tsyklu spetsialnykh dystsyplin fakhovoi pidhotovky inzhenerivelektromekhanikiv. Visnyk Kremenchutskoho natsionalnoho universytetu imeni Mykhaila Ostrohradskoho. Vypusk 3(50) Chastyna I. S.54-58 [in Ukrainian].

11. Zagirnyak M., Chornyi O., Serhiienko S. Innovative Technologies in Laboratory Workshop for Students of Technical Specialties. In: Kyiv, Proceedings of the First Ukraine Conference on Electrical and Computer Engineering (UKRCON), Kyiv, May 29-June 2, 2017. Kyiv, pp. 1216-1220. DOI: 10.1109 / UKRCON.2017.8100446 [in Ukrainian].

12. Chornyi O., Serhiienko S., Yudyna A., Sydorenko V. The analysis of the process of the laboratory practicum fulfillment and the assessment of its efficiency on the basis of the distance function. In: Kremenchuk Mykhailo Ostrohradskyi National University, Modern electrical and energy systems (MEES), Proceedings of the International Conference, Kremenchuk, November 15-17 2017. Kremenchuk. Pp. 328-331. DOI: 10.1109 / MEES.2017.8248924 [in Ukrainian].

13. Osvitno-profesiina prohrama "Elektroenerhetyka, elektrotekhnika ta elektromekhanika» Rezhym dostupu: http://saue.kdu.edu.ua/upload/documents/2020_141_prog.pdf.

14. Ohnivchuk L. M. (2014) Otsiniuvannia navchalnykh dosiahnen studentiv vyshchykh navchalnykh zakladiv na osnovi kompetentnisnoho pidkhodu. Osvitolohichnyi dyskurs. № 3 (7). S. 154-165 [in Ukrainian].

15. Zvonnykov V.Y., Chelyshkova M.B. (2012) Otsenka kachestva rezultatov obuchenyia pry attestatsyy (kompetentnostnyi podkhod): ucheb. posobye. M. 280 s. [in Russia].

16. Tytova N. M. (2010) Otsiniuvannia navchalnykh dosiahnen studentiv yak naukova problema. Naukovyi chasopys NPU imeni M. P. Drahomanova. Pedahohichni nauky: realii ta perspektyvy.. Vyp. 23. S. 324-329 [in Ukrainian].

17. Cherniavskaia A. P. (2006) Otsenyvanye uchebnokh dostyzhenyi studentov vuzov. Problemb vysshei shkoly.№ 3. S. 67-79. [in Russia].

18. Araújo R., Brant-Ribeiro T., Cattelan R., Amo S., Ferreira H.N.M. Personalization of interactive digital media in ubiquitous educational environments. In Proceedings of the IEEE International Conference on Systems, Man, and Cybernetics. Pp. 3955-3960. https://doi.org/10.1109/SMC.2013.675. [in Brazil]

19. Ferreira H.N.M., Ribeiro T., Araújo R., Dorça F., Cattelan R. An automatic and dynamic student modeling approach for adaptive and intelligent educational systems using ontologies and bayesian networks. In Proceedings of the 28th International Conference on Tools with Artificial Intelligence. Pp. 738-745. https://doi.org/10.1109/ICTAl.2016.0116. [in Brazil] 
20. Ferreira H.N.M., Oliveira G., Araújo R., Dorça F., Cattelan R. An open model for student assessment visualization. In Proceedings of the 19th IEEE International Conference on Advanced Learning Technologies. Pp. 375-379. https://doi.org/10.1109/ICALT.2019.00117. [in Brazil]

21. Ferreira H.N.M., Araújo R., Dorça F., Cattelan R. Open student modeling for academic performance visualization in ubiquitous learning environments. In Proceedings of the IEEE International Conference on Systems, Man, and Cybernetics. Pp. 641-646. https://doi.org/10.1109/SMC.2017.8122679. [in Brazil]

22. Bull S. and Wasson B. Competence visualisation: Making sense of data from 21st-century technologies in language learning, ReCALL, vol. 28. Pp. 147-165. DOl: https://doi.org/10.1017/S0958344015000282. [in USA]

23. Ali L., Hatala M., Gašević D., Jovanović J. A qualitative evaluation of evolution of a learning analytics tool Comput. Educ. 2012. 58 (1). Pp. 470-489. https://doi.org/10.1016/j.compedu.2011.08.030. [in Serbia]

24. larovyi A. (2006) Pro hnoseolohichnu pryrodu obraznoho typu piznannia. Multyversum. № 56. S. 90-101 [in Russia].

25. Shoelace Theorem. URL: https://artofproblemsolving.com/wik//index.php?title=Shoelace_Theorem (дата звернення 13.03.2021)

26. Polygon Area. URL: https://mathworld.wolfram.com/PolygonArea.html (дата звернення13.03.2021)

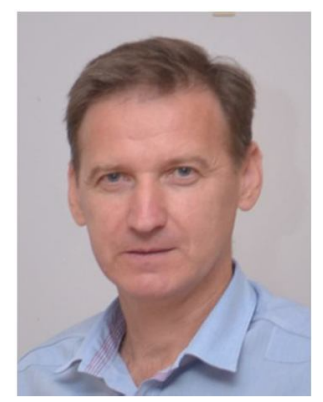

\section{Чорний Олексій Петрович.}

Доктор технічних наук, профресор,

директор Навчально-наукового інституту електромеханіки, енергозбереження і систем управління, Кременчуцький національний університет імені Михайла Остроградського,

вул. Першотравнева, 20, Кременчук, Україна

Тел. +380675417900. E-mail: alekseii.chornyi@gmail.com

\section{Chornyi Oleksii.}

Doctor of Technical Sciences, Professor,

Director of the Educational and Scientific Institute of Electromechanics, Energy Saving and Control

Systems,

Kremenchuk Mykhailo Ostrohradskyi National University,

vul. Pershotravneva, 20, Kremenchuk, Ukraine.

Phone: +380675417900. E-mail: alekseii.chornyi@gmail.com

ORCID: 0000-0001-8270-3284

Scopus ID: 57039206300

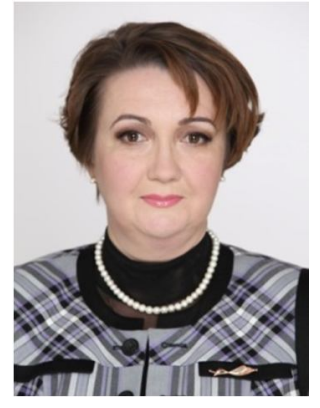

Герасименко Лариса Віталіївна.

Доктор педагогічних наук, доцент,

професор кафедри психології, педагогіки та філософії,

Кременчуцький національний університет імені Михайла Остроградського,

вул. Першотравнева, 20, Кременчук, Україна.

Тел. +380679004365. E-mail: gerasimenko24@gmail.com

\section{Herasymenko Larysa.}

Doctor of Pedagogy, Associate Professor,

Professor of the Department of Psychology, Pedagogy and Philosophy,

Kremenchuk Mykhailo Ostrohradskyi National University,

vul. Pershotravneva, 20, Kremenchuk, Ukraine.

Phone: +380679004365. E-mail: gerasimenko24@gmail.com

ORCID: 0000-0003-3725-8681

Scopus ID: 57220200045

\section{Citation (APA):}

Chornyi, O., Herasymenko, L. (2021). Formation assessment of the professional competences of electrical engineers specialists.

Engineering and Educational Technologies, 9 (1), 40-51. doi: https://doi.org/10.30929/2307-9770.2021.09.01.04

\section{Цитування (ДСТУ 8302:2015):}

Чорний О. П., Герасименко Л. В. Оцінка сформованості фрахових компетентностей / Інженерні та освітні технології. 2021. Т. 9. № 1. C. 40-51. doi: https://doi.org/10.30929/2307-9770.2021.09.01.04

Обсяг статmі: сторінок - 12; умовних друк. аркушів - 1,738. 